\title{
Effect of Petroleum Hydrocarbons Contamination on Soil Microorganisms and Biodegradation
}

\author{
Raghad N. Hazim \\ Mehjin A. Al-Ani \\ Department of Environmental Technology/College of Environmental Sciences and Technology/ \\ University of Mosul \\ E-mail: raghadnawfal1991@gmail.com \\ E-mail: mehjin2002@yahoo.com
}

(Received 15/7/2018 ; Accepted 27/9/2018)

\begin{abstract}
The experiment under lab condition was conducted to investigate the effect of petroleum hydrocarbon contamination on soil microorganisms and biodegradation. The experiment was conducted in 12 treatment and three replication. The treatments include soil contaminated with Kerosene, Diesel, lubricate oil and used lubricate oil in three concentration $0 \%, 5 \%$, and $10 \%$. contamination with hydrocarbons significantly decreased the count of heterotrophic bacteria and there was reversal relationship between the contaminant concentration and the count of heterotrophic bacteria. The results indicated soil contamination with hydrocarbons significantly increased the count of Hydrocarbon Utilizing Bacteria (HUB). The effect of petroleum hydrocarbons on fungi count differed according to the type of hydrocarbons, concentration of contaminant and the periods of incubation. Our results show that soil contamination by hydrocarbons caused significant increase in actinomycetes count at all hydrocarbon types and concentrations except 5\% used and non-used lubrication oil. The higher percentage of biodegradation in hydrocarbons contaminated soil $49.6 \%$ was recorded in soil contaminated with $5 \%$ kerosene while the lower percentag $10.8 \%$ was recorded with soil contaminated $10 \%$ lubricate oil.
\end{abstract}

Keywords: Hydrocarbons, soil microorganisms, HUB.

\section{تأثير الهيروكاربونلت الفلية عل لحياء التربة المجهربة والنحل الحيوي}

\begin{abstract}
المالخص
دس في هذا البهث تأثير الهيدروكاربونت النطية على لحياء التربة المجهرية والتحل الحيوي حيث لجريت تججربة

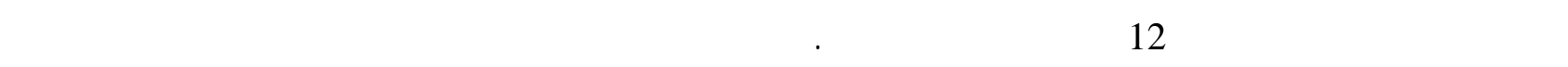

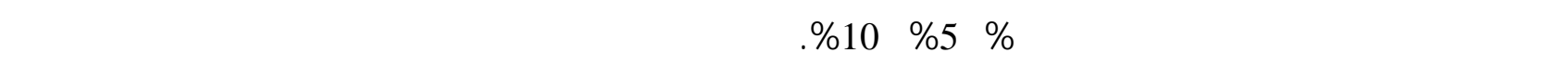

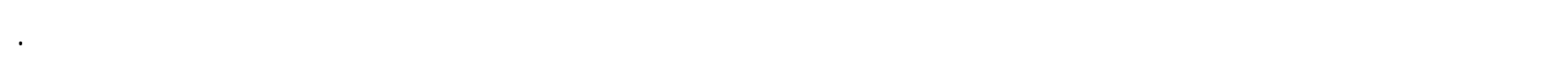

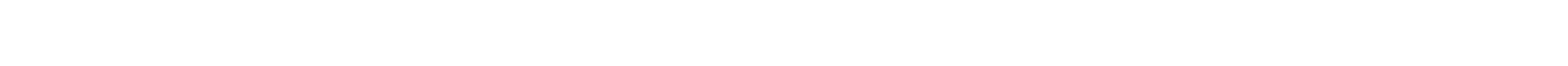

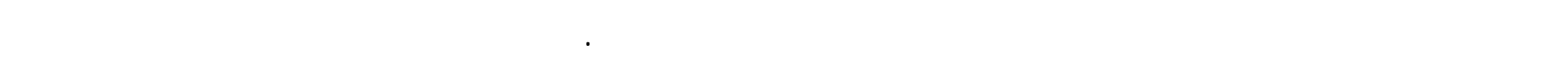

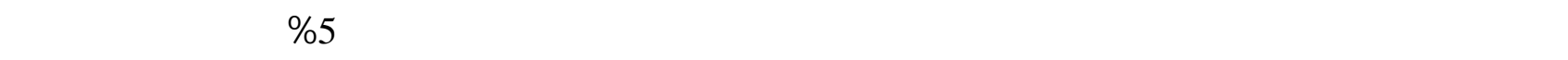

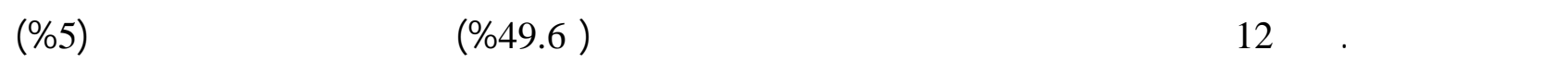
كيروسين بينماسجلت القل نسبة تحل حيوي (10.8\%) مع التربة الملوثة ( 10\%) زيت تشحيم. الكاملت الدالة: هيدروكربونات، لحياء تربة مجهرية، تلوث.
\end{abstract}




\section{INTRODUCTION}

Considering the rapid growth in the world's population, crude oil continues to be the main source of energy and raw material for industries worldwide (Abbasian et al., 2016). The increasing demand on petroleum products drives a surge in production, transportation and refinery - resulting in an inevitable toll on the environment (Gallego et al., 2001). Indeed, increased oil production and distribution is associated with higher incidents of pollution due to oil spillage (Hussain and Gondal, 2008). Furthermore, natural causes such as superficial waters and floods can spread this contamination to other areas (Zakaria, 2002). Crude oils typically consist of various types of hydrocarbons (aliphatic and aromatic). While these hydrocarbons contain plenty of carbon and hydrogen atoms, they are very nutritionally poor and insufficient to sustain many microorganism species (Abbasian et al., 2016; Sathishkumar et al., 2008; Viñas et al., 2005). The toxicity of these hydrocarbons to microorganisms means that contaminated soil may experience drastic changes to the population and abundances of various microbial species (Abbasian et al., 2015; Megharaj et al., 2011). The extent of these changes to the microbial populations is dependent on several factors including: the composition of the microbial community prior to the contamination, the chemical composition of the contaminant (crude oil), and the physiochemical factors of the contamination site (Abbasian et al., 2016; Rahman et al., 2002a). Certain microbial species face a challenge when grown in the presence of hydrocarbons due to their hydrophobicity and insolubility - leading to restriction of absorption by these cells, ultimately leading toxicity (Abbasian et al., 2015). Moreover, these hydrocarbons affect the microorganisms membrane fluidity; thus, microorganism exposed to petroleum products must adapt their membrane structure to survive (Jin et al., 2014). The extent of these changes are depending on the type of hydrocarbon contaminant and their carbon chain length (Abbasian et al., 2015). Some hydrocarbon-degrading microorganisms learn to adapt by producing and secreting a surfactant compounds to emulsify the hydrocarbon and form micelles - to be taken up later in various ways (Abbasian et al., 2015; Bustamante et al., 2012). Microorganisms are a key player in maintaining sustainable environment and ecosystem (Varjani, 2017). Microorganisms are known to be the most effective tools to naturally degrade crude oil after a spillage episode. Bioremediation is a process in which microorganism are utilized to convert dangerous organic pollutants from crude oil into environmentally friendly compounds such as $\mathrm{CO}_{2}$ and $\mathrm{H}_{2} \mathrm{O}$ (Ron and Rosenberg, 2014; Varjani, 2017). In the process of biodegradation, oleophilic microbes are utilized and administrated to degrade the hydrocarbons and remediate the site of spillage (Varjani and Upasani, 2013). since microorganisms are naturally effective to degrade petroleum products, it is important to understand the changes in microbial diversity post soil contamination with various petroleum products (Abbasian et al., 2016). In this study, we aimed to understand the changes in indigenous soil microbial diversity and abundances upon the addition of kerosene, diesel, and non-used and used lubricate oil. Our study will also evaluate the ability of the various soil indigenous microorganism species to biodegrade of these petroleum products.

\section{Soil Sampling and Analysis}

\section{MATERIALS AND METHODS}

The soil was collected from Basheka area $12 \mathrm{~km}$ Northeast of Mosul. The soil collected from surface area $(0-20) \mathrm{cm}$. The soil air died sieved with $2 \mathrm{~mm}$ sieve to remove debris. The physical and chemical properties of the soil were determined as following. Soil texture by hydrometer method, Soil Reaction $(\mathrm{pH})$ by glass electrode method (1:2.5 soil water suspension) (CON 720), soluble salts by Electrical Conductivity (conductivity bridge method) (Inolab pH 720), Organic Content by rapid titration method (Black et al., 1965), available phosphorus by Olsen's method (Olsen et al., 1954) Ca and Mg by titration with EDTA (Graham et al., 1962), Potassium and sodium by flame photometer (PFP 7) (Jackson, 1973). Some of soil physical and chemical properties were recorded in (Table 1). 


\section{Experimental Design}

$200 \mathrm{gm}$ of sieved soil was placed in $250 \mathrm{ml}$ volumetric flask. The petroleum hydrocarbon treatments comprised of four different petroleum fractions Kerosene(K), Diesel (D), lubricate oil (O) and used lubricate oil(UO) ). Treatment were applied at $0 \%, 5 \%$ and $10 \%$ levels. The petroleum hydrocarbon contamination involved twelve treatments in a completely randomized design replicated three times. All components were thoroughly mixed with the soil. The moisture content of soil was brought to $65 \%$ water holding capacity. Soil was turned weekly and distilled water was added to maintain them $65 \%$ of WHC. The beakers were incubated at a temperature of $25 \mathrm{C}$. Soil sampling was carried out at one month and subsequently biweekly intervals for 12 weeks (Alrumman et al., 2015).

\section{Microbial Count}

In estimating microbial population, standard plate count methods were used to prepare nutrient agar (NA) for estimation of the heterotrophic bacteria, potato dextrose agar (PDA) for estimation of fungi, Starch casein nitrate (SCN) agar for estimation of actinomycetes, and Luria bertani agar (LBA) ( in LBA yeast extract was replaced with kerosene, diesel or lubricate oil as carbon source) for estimation of hydrocarbon utilizing bacteria (HUB). One gram each of the soil samples were measured into the test tube containing $9 \mathrm{ml}$ sterile distilled water and serially diluted to dilution factor $10^{5}$ and $1 \mathrm{ml}$ of the last dilutions was pipette into sterile plate with appropriate medium which were incubated at $28^{\circ} \mathrm{C}-30^{\circ} \mathrm{C}$. All plated were incubated inverted wise. Microbial counted were done at 48 hours for NA and 72 hours for PDA and 72 hours for LBA and 6 days for(SCN) (Stanley et al., 2015; Desai, 2015; Adesina and Adelasoye, 2014).

\section{Hydrocarbons Determination}

To extract the hydrocarbons from soil.10 g of soil was placed in a dry baker and add $10 \mathrm{ml}$ of organic solvent (hexane). The solvent filtered and placed in a weighted baker and dried in the 80 C. The precipitate was weighted. the percentage of remaining hydrocarbons in soil were calculated (Mishra et al., 2001)

\section{Statistical Analysis}

ANOVA and correlation analyses were carried out. The means were compared using Duncan's test at $\mathrm{p}<0.05$ after, ANOVA. The relationships between HUB and percentage of hydrocarbon biodegradation were determined using Pearson’s correlation analysis.

\section{Soil Properties}

\section{RESULTS AND DISCUSSION}

Table (1) shows some physical and chemical properties for soil under study.

Table 1: some soil physical and chemical properties

\begin{tabular}{|c|c|c|c|}
\hline Characteristics & Results & Characteristics & Results \\
\hline $\mathrm{pH}$ & 7.1 & $\mathrm{~K}(\mathrm{meq} / \mathrm{L}$ & 108 \\
\hline $\mathrm{Ec}$ & 433 & $\mathrm{So}_{4}(\mathrm{meq} / \mathrm{L})$ & 26.47 \\
\hline $\begin{array}{c}\text { Organic matter } \\
\text { Available Phosphorus } \\
(\mathrm{mg} \backslash \mathrm{L})\end{array}$ & 1.03 & Clay (\%) & 22.7 \\
\hline $\mathrm{Ca}(\mathrm{meq} / \mathrm{L})$ & 1.5 & Silt ( \% ) & 49.25 \\
\hline $\mathrm{Mg}(\mathrm{meq} / \mathrm{L}$ & 13 & Sand( \% ) & 28.05 \\
\hline
\end{tabular}

\section{Heterotrophic Bacteria Count}

The Fig. (1) shows the total aerobic heterotrophic bacterial counts for the control (uncontaminated) soil ranged from $0.2 .18 \times 10^{5}$ colony forming unit $\left(\mathrm{CFUg}^{-1}\right)$ soil to $2.83 \times 10^{5}$ $\mathrm{CFUg}^{-1}$ soil while counts for 5\%, 10\% kerosene, 5\%, 10\% diesel oil, 5\%, 10\% non-used lubrication oil and $5 \%, 10 \%$ used lubrication oil contaminated soils ranged from $1.49 \times 10^{5}$ to $1.87 \times 10^{5}$ $\mathrm{CFU}^{-1}$ soil, $0.96 \times 10^{5} \mathrm{CFUg}^{-1}$ soil to $1.63 \times 10^{5} \mathrm{CFUg}^{-1}$ soil and $1.29 \times 10^{5} \mathrm{CFUg}^{-1}$ to $1.79 \mathrm{x}$ $10^{5} \mathrm{CFUg}^{-1}$ soil $1.03 \times 105$ to $1.32 \times 10^{5} \mathrm{CFUg}^{-1}, 1.05 \times 10^{5}$ to $1.32 \times 10^{5} \mathrm{CFUg}^{-1}$ soil and $0.9 \mathrm{x}$ $10^{5}$ to1.13 x $10^{5} \mathrm{CFUg}^{-1}$ soil, $1.19 \times 105$ to $1.51 \times 10^{5} \mathrm{CFUg}^{1-}$ soil and $0.88 \times 105$ to $1.16 \times 105$ 
$\mathrm{CFUg}^{-1}$ soil respectively. The results indicated soil contamination with hydrocarbons significantly decreased the count of heterotrophic bacteria and there was reversal relationship between the contaminant concentration and the count of heterotrophic bacteria. After twelve weeks incubation. Soil contamination with $5 \%$ and $10 \%$ of each hydrocarbon kerosene, 5 and $10 \%$ diesel, 5 and 10\% non-used lubricate oil and 5 and 10\% used lubricate oil decreased heterotrophic bacteria 23\%, 39\%, 24\%, 44\%, 44\%,52\%, 42\% and 50\% respectively and these results are consistent with (Kucharski et al., 2004; Wyszkowska and Kucharski, 2001; Adesina and Adelasoye, 2014) who concluded the hydrocarbon contamination soil cause decrease of heterotrophic bacteria count and increase heavy metals concentration and they suggested decreases in both count and diversity of bacteria communities in hydrocarbon contaminated soils are caused by presence of toxin effect for heavy metals. Our results show that there were no significant differences in count of heterotrophic bacteria between soil contaminated with non-used and used lubricate oil

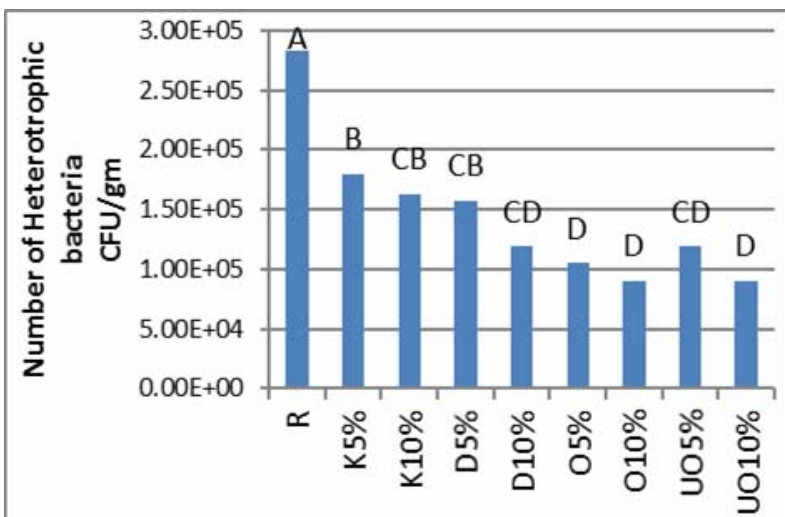

Hydrocarbon Types After 4 weeks of incubation
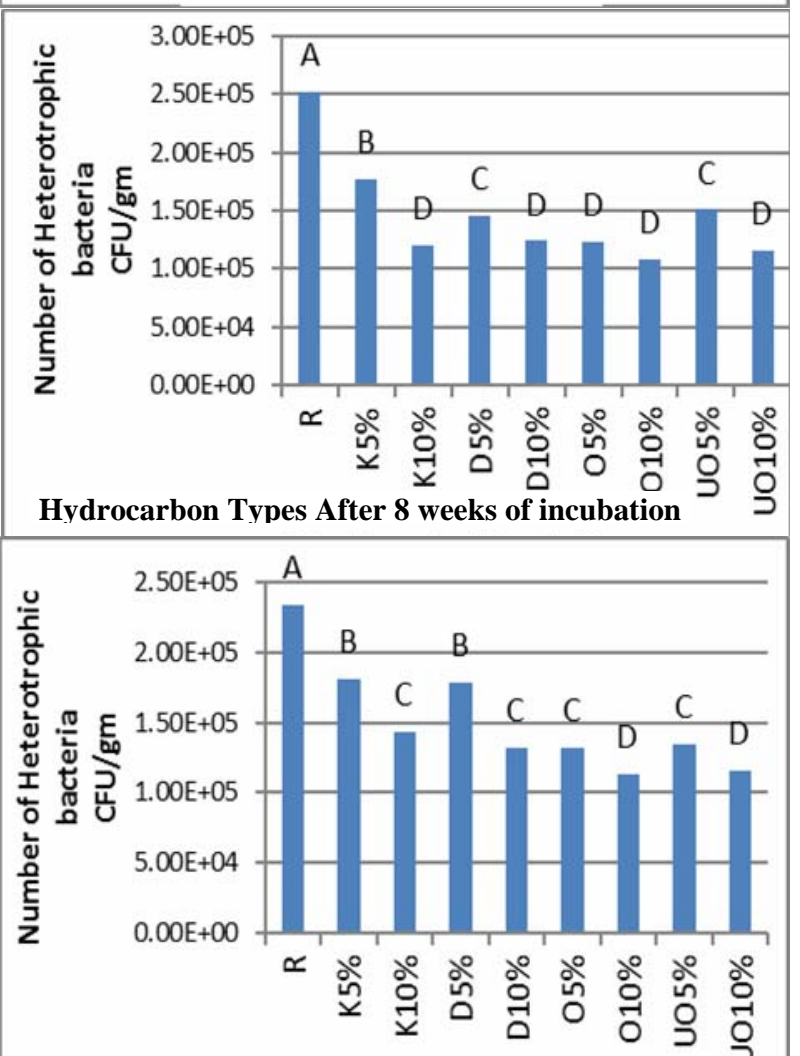

Hydrocarbon Types After 12 weeks of incubation

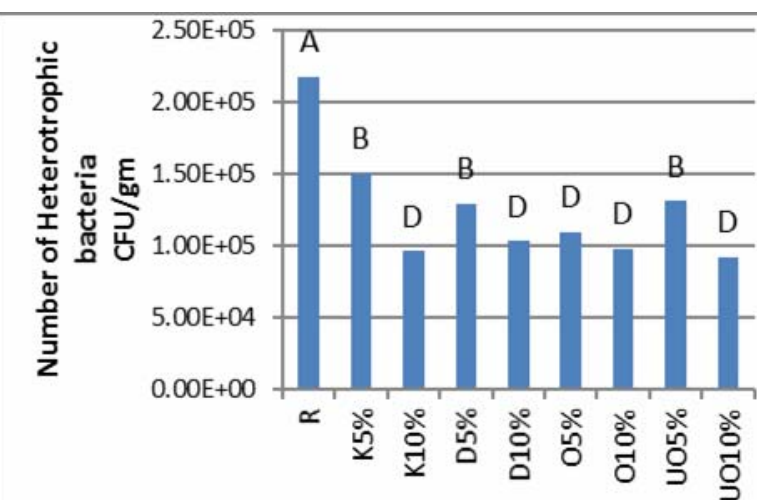

Hydrocarbon Types After 6 weeks of incubation

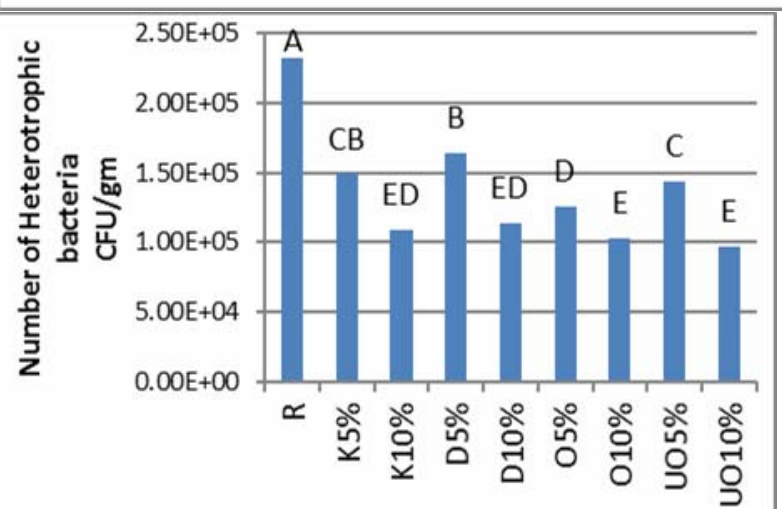

Hydrocarbon Types After 10 weeks of incubation

Deferent letters above the bars show significant differences $(\mathbf{p}<\mathbf{0 . 0 5})$

$\mathbf{R}=$ Uncontaminated soil (control)

$\mathrm{K}=$ Kerosene

$\mathbf{D}=$ Diesel

$\mathbf{O}=$ Lubricating oil

UO = Used lubricating oil

Fig. 1: Effect of soil contaminated with hydrocarbons on heterotrophic bacteria count Hydrocarbon Utilizing Bacteria (HUB) Count 
The Fig. (2) shows the HUB counts for the control (uncontaminated) soil ranged from $0.45 \mathrm{x}$ $10^{5}$ soil to $0.94 \times 10^{5} \mathrm{CFUg}^{-1}$ soil, while counts for $5 \%, 10 \%$ kerosene and $5 \%, 10 \%$ diesel oil., $5 \%, 10 \%$ non-used lubrication oil and 5\%,10\% used lubrication oil contaminated soils ranged from $1.49 \times 10^{5}$ to $1.85 \times 10^{5} \mathrm{CFU}^{-1}$ soil, $2.14 \times 10^{5}$ to $2.52 \times 10^{5} \mathrm{CFUg}^{-1}$ soil, $1.12 \times 10^{5}$ to $1.44 \times$ $10^{5} \mathrm{CFUg}^{-1}$ soil, $1.30 \times 10^{5}$ to $2.02 \times 10^{5} \mathrm{CFUg}^{-1}, 1.16 \times 10^{5}$ to $1.36 \times 10^{5} \mathrm{CFUg}^{-1} \mathrm{~g}$ soil, $0.85 \mathrm{x}$ $10^{5}$ to $1.44 \times 10^{5} \mathrm{CFUg}^{-1}, 1.12 \times 105$ to $1.38 \times 10^{5} \mathrm{CFUg}^{-1} \mathrm{~g}$ and $0.90 \times 10^{5} \mathrm{CFUg}^{-1}$ to $1.16 \times 10^{5}$ $\mathrm{CFUg}^{-1}$ respectively. The results indicated soil contamination with hydrocarbons significantly increased the count of HUB. After 12 weeks incubation. Addition of 5\%, 10\% Kerosene, 5\%, 10\% Diesel, 5\%, $10 \%$ lubricate oil and 10\% used lubricate oil, 5\% used lubricate oil and 10\% used lubricate oil increased HUB 294\%, 436\%, 206\%, 330\%, 206\%, 168\%, 174\% and 147\%. Respectively. Our results show during all periods of incubation the addition of $10 \%$ kerosene was record the higher increased percentage in HUB count however the addition $10 \%$ of non-used lubricate oil recorded the lower increase percentage in HUB count. This result agreed with (Lawlor et al., 1997; Das and Chandran, 2011; Amrazaitiene et al., 2013; Markowicz et al., 2016; Cueva et al., 2016) who reported higher population of HUB in hydrocarbon polluted soil due to the UBH can utilize hydrocarbon as carbon and energy sources this favored condition for the rapid replication led to higher population of HUB.

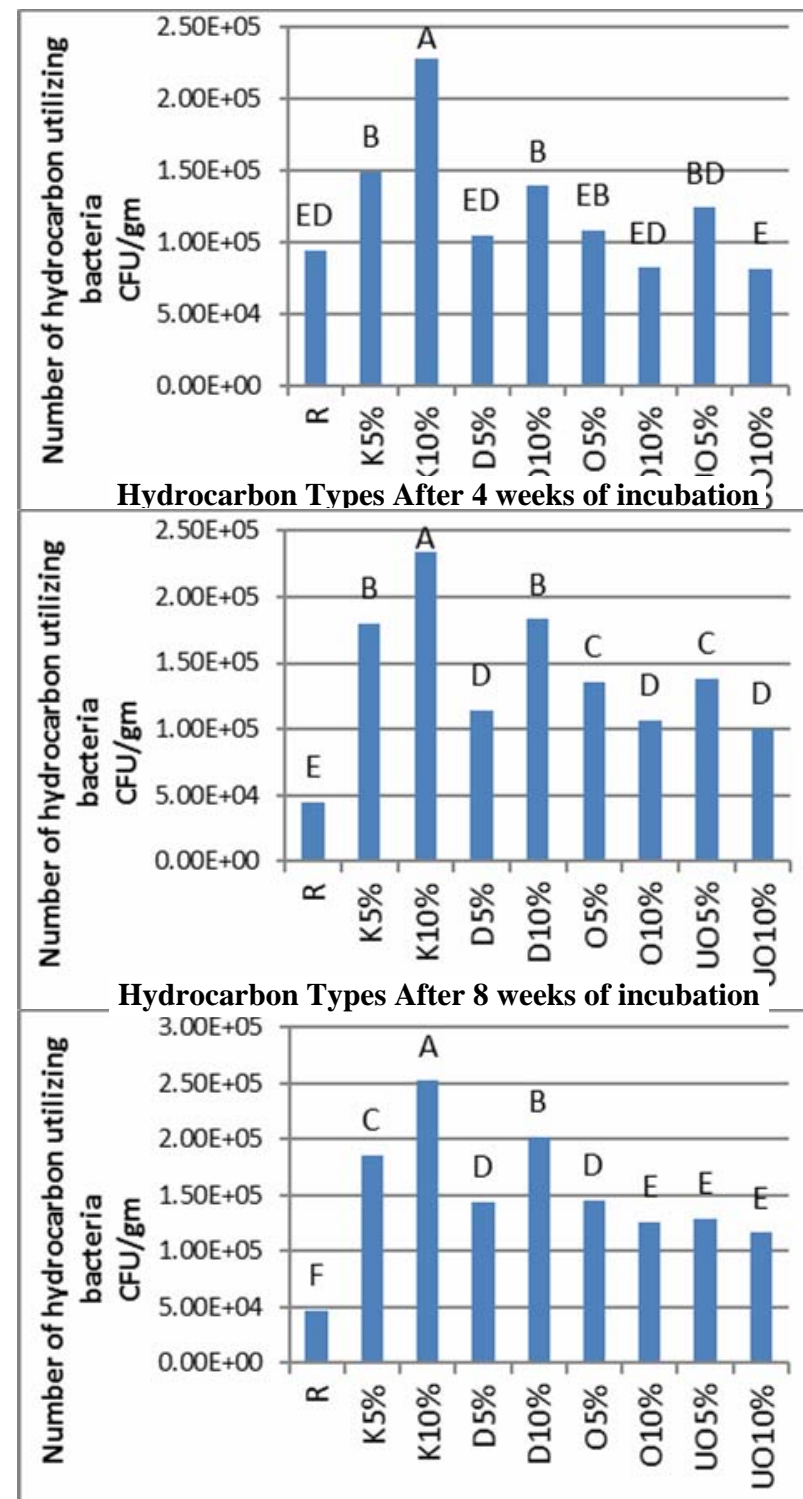

Hydrocarbon Types After 12 weeks of incubation

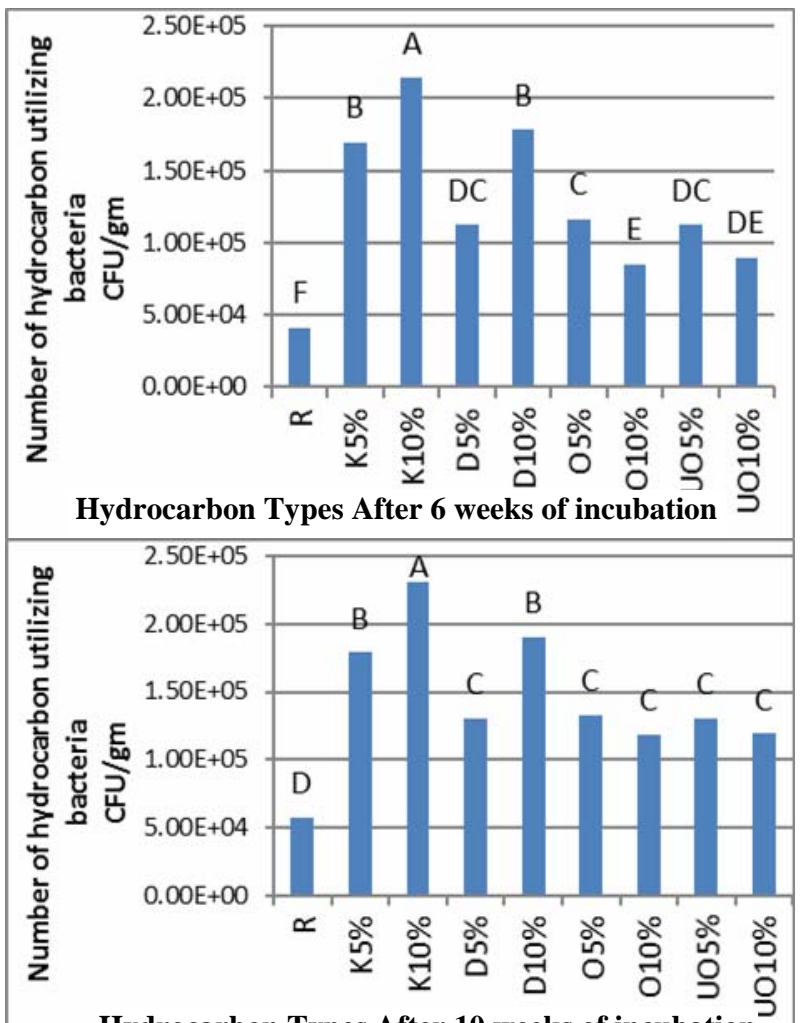

Hydrocarbon Types After 10 weeks of incubation

Deferent letters above the bars show significant differences $(\mathbf{p}<\mathbf{0 . 0 5})$

$\mathbf{R}=$ Uncontaminated soil (control)

$\mathrm{K}=$ Kerosene

$\mathbf{D}=$ Diesel

$\mathbf{O}=$ Lubricating oil

UO = Used lubricating oil

Fig. 2: Effect of soil contaminated with hydrocarbons on hydrocarbon utilizing bacteria (HUB) count 


\section{Fungi Count}

Fig. (3) shows the effect of petroleum hydrocarbons on fungi count differed according to the type of hydrocarbons, concentration of contaminant and the periods of incubation. Soil contamination with $10 \%$ deasil, $10 \%$ lubricate oil and $10 \%$ used lubricate oil increased fungi count after four, six and ten weeks incubation. while soil contaminated with 5\% kerosene, 5\% diesel. 5\% non-used oil and 5\% used oil decreased fungi count after periods 4, 6 and 10 weeks incubation while after 12 weeks incubation. Soil contamination at all studied hydrocarbons and concentration increased fungi count. Soil contamination with 5\%, 10\% kerosene, 5\%, 10\% diesel oil., 5\%, 10\% non-used lubrication oil and 5\%,10\% used lubrication increased fungi count $29 \%$, 49\%, 73\%, $139 \%, 37 \%, 80 \%, 54 \%$, and $122 \%$ respectively. The increase of fungi count at later periods may be due to the fungi need a time to adapt to new circumstances (hydrocarbon polluted). These results are consistent with Lawlor et al., 1997; Xenia and Refugio, 2016 who reported the increased in fungi count due to the ability of some of the fungi to utilize hydrocarbons as carbon and energy sources.

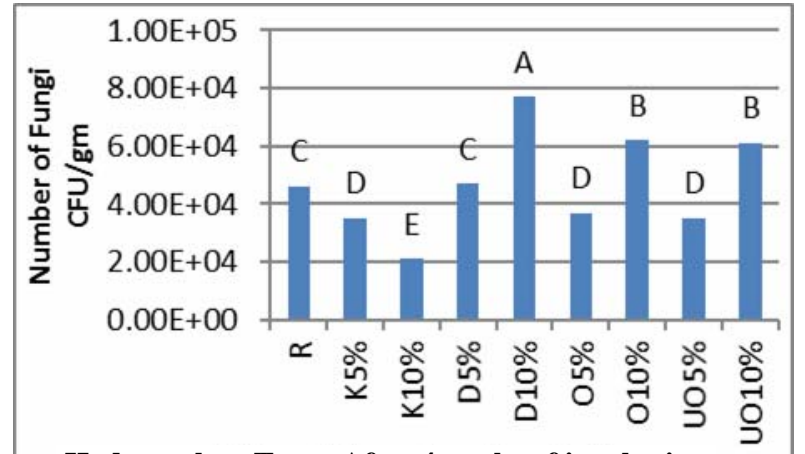

Hydrocarbon Types After 4 weeks of incubation

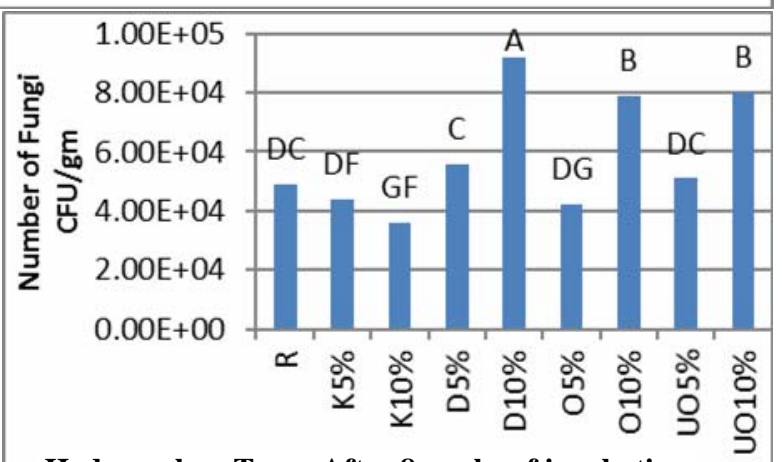

Hydrocarbon Types After 8 weeks of incubation

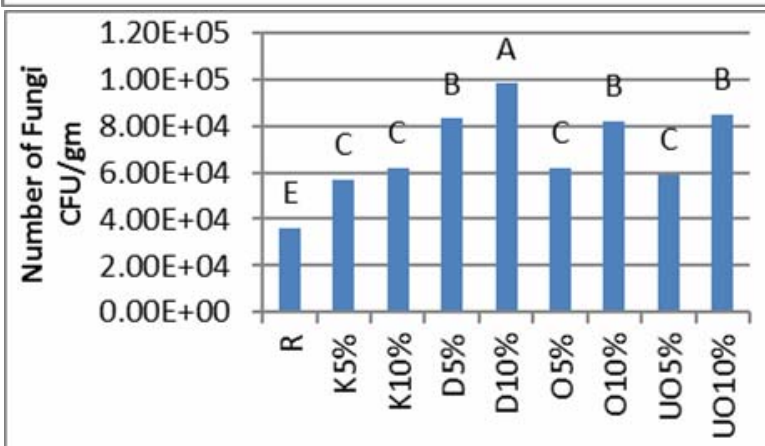

Hydrocarbon Types After 12 weeks of incubation

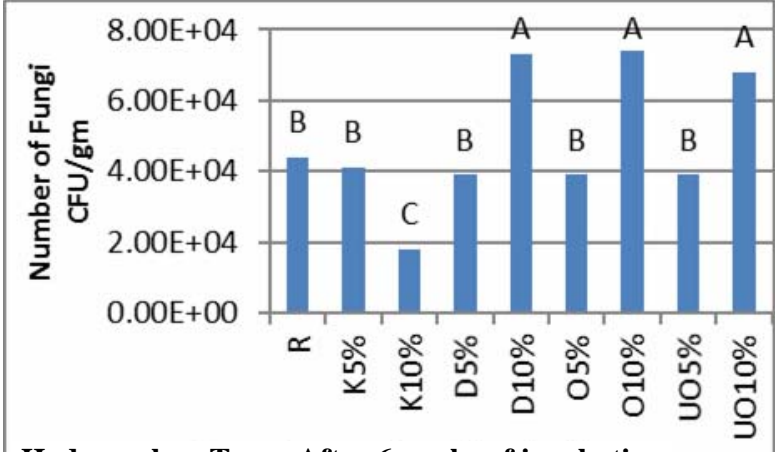

Hydrocarbon Types After 6 weeks of incubation

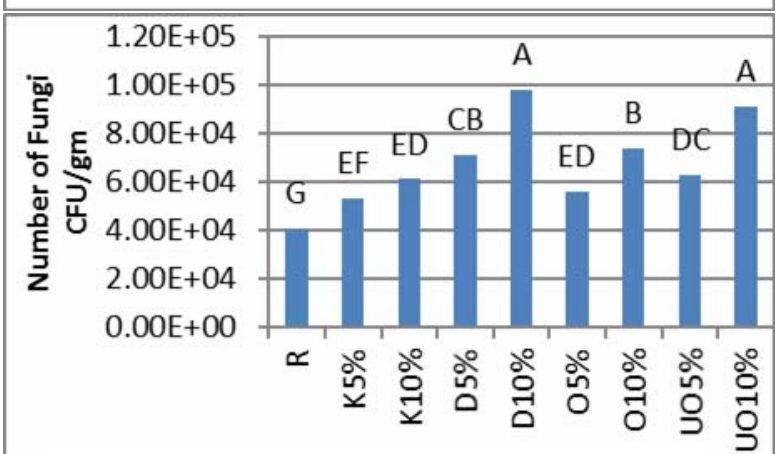

Hydrocarbon Types After 10 weeks of incubation

Deferent letters above the bars show significant differences $(\mathbf{p}<\mathbf{0 . 0 5})$

$\mathbf{R}=$ Uncontaminated soil (control)

$\mathrm{K}=$ Kerosene

D = Diesel

$\mathbf{O}=$ Lubricating oil

UO = Used lubricating oil

Fig. 3 : Effect of soil contaminated with hydrocarbons on Fungi count Actinomycetes Count 
The Fig. (4) shows the actinomycetes counts for the control (uncontaminated) soil ranged from $0.51 \times 10^{5}$ to $0.63 \times 10^{5} \mathrm{CFUg}^{-1}$ soil while counts for $5 \%, 10 \%$ kerosene, $5 \%, 10 \%$ diesel oil, $5 \%, 10 \%$ lubrication oil and $5 \%, 10 \%$ used lubrication oil contaminated soils ranged from $0.94 \times 10^{5}$ soil to $1.17 \times 10^{5} \mathrm{CFU}^{-1}$ soil, $1.27 \times 10^{5}$ to $2.03 \times 10^{5} \mathrm{CFUg}^{-1}$ soil, $0.89 \times 10^{5}$ to $1.11 \times 10^{5} \mathrm{CFUg}^{-1}$ soil, $1.27 \times 10^{5}$ to $2,09 \times 10^{5} \mathrm{CFUg}^{-1} \mathrm{~g}$ soil, $0.48 \times 10^{5}$ to $0.77 \times 10^{5} \mathrm{CFUg}^{-1}$ and $0.57 \times 10^{5} \mathrm{CFUg}^{-1}$ to1.16 $\times 10^{5} \mathrm{CFUg}^{-1}$ soil, $0.45 \times 105$ to $0.81 \times 10^{5} \mathrm{CFUg}^{-1}$ soil and $^{-10}$ $0.92 \times 105 \mathrm{CFUg}_{-}{ }^{1}$ soil to $1.16 \times 105 \mathrm{CFUg}^{-1}$ soil respectively. Our result show soil contaminated by hydrocarbons significantly increased actinomycetes count at all hydrocarbon types and concentrations except 5\% used and non-used lubrication oil. These results agree with (Schippers et al, 2005; Hamamura et al., 2013) who concluded actinomycetes can utilize hydrocarbons as carbon and energy sources. (Goodfello and Williams, 1983) reported actinomycetes are the most important microorganisms that have the ability degrade and analyze organic matter because they have many enzymatic systems capable of biodegrade organic matter

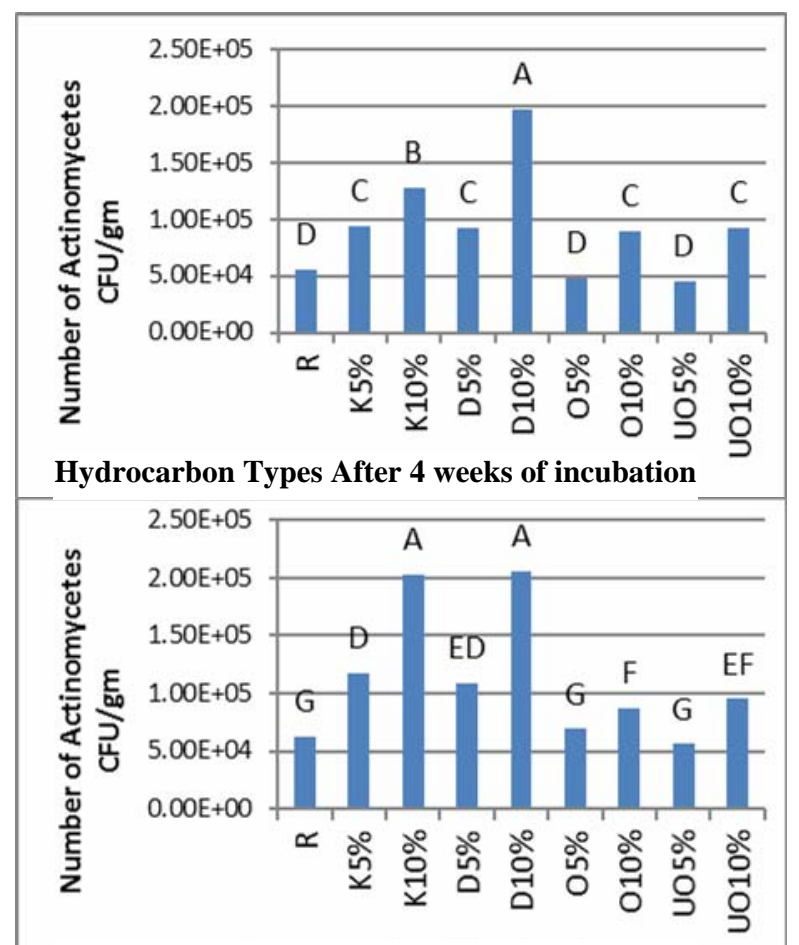

Hydrocarbon Types After 8 weeks of incubation

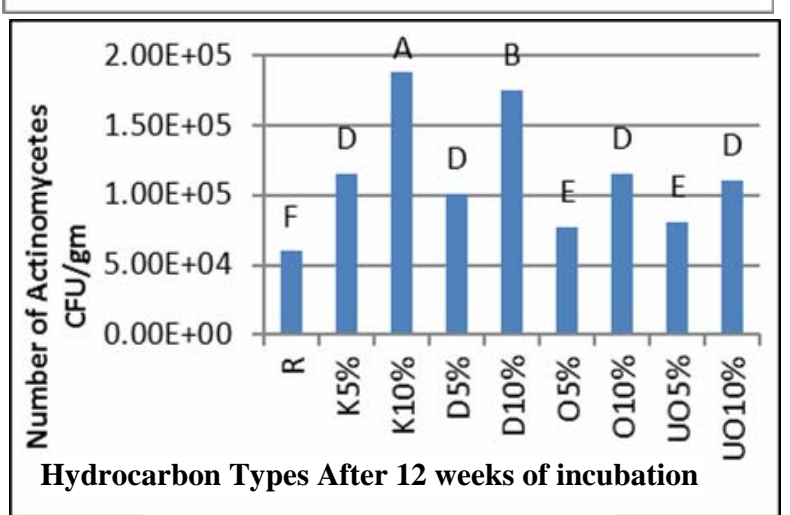

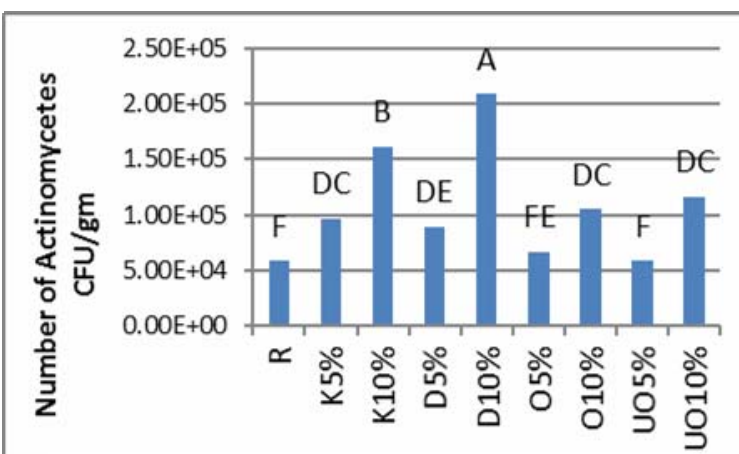

Hydrocarbon Types After 6 weeks of incubation

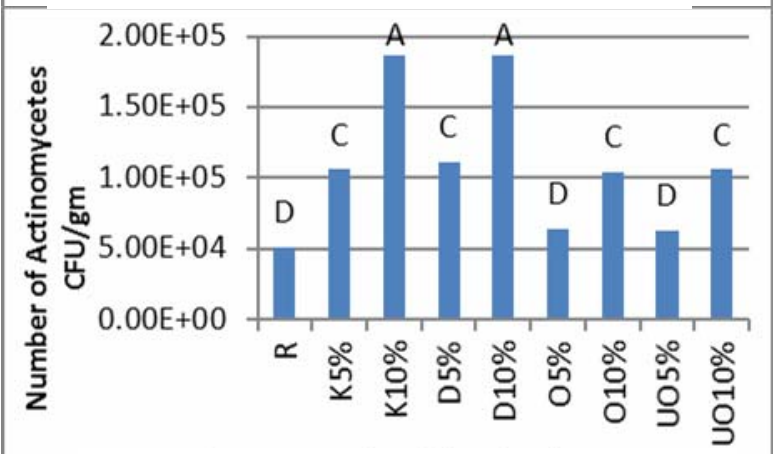

Hydrocarbon Types After 10 weeks of incubation

Deferent letters above the bars show significant differences $(\mathbf{p}<\mathbf{0 . 0 5})$

$\mathbf{R}=$ Uncontaminated soil (control)

$\mathrm{K}=$ Kerosene

$\mathbf{D}=$ Diesel

$\mathrm{O}=$ Lubricating oil

UO = Used lubricating oil

Fig. 4: Effect of soil contaminated with hydrocarbons on Actinomycetes count 


\section{Hydrocarbons Biodegradation}

The percentage of hydrocarbons biodegradation in the soil contaminated with $5 \%$ and $10 \%$ of kerosene, diesel, lubricate oil and used lubricating oil is shown in (Table 2). At the end of twelve weeks the result indicate the higher percentage of biodegradation $49.6 \%$ was recorded in soil contaminated with $5 \%$ kerosene while the lower percentage of biodegradation $10.8 \%$ was recorded with soil contaminated $10 \%$ non- used lubricate. The percentage of hydrocarbons biodegradation in the soil contaminated with 5\% diesel, 5\% non-used lubricate oil and 5\% used lubricate oil were $32 \%, 28 \%$ and $24 \%$ respectively. However the biodegradation of Kerosene 10\%, diesel 10\%, and used lubricate oil were $30 \%, 25.6 \%$ and $12.4 \%$ respectively. Positive correlation was found between HUB count and percentage of hydrocarbons biodegradation. Our results show there was reversal relationship between hydrocarbons biodegradation percentage and the contaminant concentration and this consistence with (Boldu-Prenafeta et al., 2004; Ambrazaitiene et al., 2013; Abioye et al., 2012; Rahman et al., 2002b). High concentration of contaminant causing decreasing in biodegradation percentage due to high concentration can be inhibitory of microorganisms by toxic effects (Abioye et al., 2012; Rahman et al., 2002b; Ijah and Antai, 2003) for this reason reported that bioremediation is a useful method of soil remediation if contaminant concentrations are moderate. Also the results show there are differences between biodegradation percent of hydrocarbons and these results agreed with (Ambrazaitiene et al., 2013; Boldu-Prenafeta et al., 2004) who concluded the rate of biodegradation depends on the microbial population, the type, structure and level of contamination. The biodegradation percentage in hydrocarbons contaminated soil was in the order of kerosene $>$ Diesel $>$ lubricate oil $>$ used lubricate oil. The kerosene, diesel, and lubricate oil consisted mainly of n-alkanes with chain length of C10-C16, C10-C22 and C15 C50 respectively. These result consistence with (Wang et al., 1998) who concluded the biodegradation rate of n-alkane inverse proportional with chain length and branched alkanes less ability to biodegradation. The results show there was no huge differences in biodegradation percentage between non-used and used lubricate oil.

Table 2: Biodegradation of contaminant hydrocarbons in soil after 12 weeks of incubation

\begin{tabular}{|c|c|c|}
\hline Contaminated Hydrocarbons & $\begin{array}{c}\text { Residual } \\
\text { Hydrocarbon } \\
\text { \% }\end{array}$ & $\begin{array}{c}\text { Hydrocarbon } \\
\text { Biodegradation \% }\end{array}$ \\
\hline K 5\% & $50.4 \%$ & $49.6 \%$ \\
\hline K 10\% & $70 \%$ & $30 \%$ \\
\hline D 5\% & $68 \%$ & $32 \%$ \\
\hline D 10\% & $74.4 \%$ & $25.6 \%$ \\
\hline O 5\% & $72 \%$ & $10.8 \%$ \\
\hline O 10\% & $89.2 \%$ & $24 \%$ \\
\hline UO 5\% & $76 \%$ & $12.4 \%$ \\
\hline UO 10\% & $87.6 \%$ & \\
\hline K = Kerosene & O = Lubricating oil \\
D = Diesel & UO Used lubricating oil \\
\hline
\end{tabular}

\section{REFERENCES}

Abbasian, F.; Lockington, R.; Megharaj, M.; Naidu, R. (2016). The biodiversity Changes in microbial population of soils contaminated with crude oil. Curr. Microbiol. 72(6), 663670.

Abbasian, F.; Lockington, R.; Mallavarapu, M.; Naidu, R. (2015). A comprehensive review of aliphatic hydrocarbon biodegradation by bacteria. Appl. Biochem. Biotechnol. 17, 670699. 
Abioye, O.; Agamuthu, P.1.; AbdulAziz, A. (2012). Biodegradation of used motor oil in soil using organic waste Amendments. Biotechnology Research International. 2012, 1-8

Adesina, G.O.; Adelasoye, K.A. (2014). Effect of crude oil pollution on heavy metal contents, microbial population in soil, and maize and cowpea growth. Agricultural Sci., 5(1), 43-50.

Alrumman, S.A.; Standing, D.B.; Paton, G.I. (2015). Effects of hydrocarbon contamination on soil microbial community. J. King Saud University- Sci., 27, 31-41

Ambrazaitiene, D.; Žukauskaite, A.; Jakubauskaite, V.; Reikaitei, R.; Zubrickaite, M.; Karcauskiene, A. (2013). Biodegradation activity in the soil contaminated with oil products. Zemdirbyste- Agriculture. 100(3), 235-242.

Black, C.A.; Evanus, D.D.; White, J.L.; Newsmonger, L.E.; Clark, F.E. (1965) "Method of Soil Analysis". Chemical And Microbiological Properties. The American Soc. Agr. Inc., New York.

Boldu-Prenafeta, F.X.; Ballerstedt, H.; Gerritse, J.; Grotenhuis, J.T.C. (2004). Bioremediation of BTEX hydrocarbons: effect of soil inoculation with the toluene-growing fungi Cladophialopora sp. Strain T1. Biodegradation, 15(1), 59-65.

Bustamante, M.; Durán, N.; Diez, M.C. (2012). Biosurfactants are useful tools for the bioremediation of contaminated soil: a review. J. Soil Sci. Plant Nutr. 12, 667-687.

Cueva, S.C.D.; Rodriguez, C.H.; Cruz, N.O.S.; Contreras, J.A.R.; Miranda, J.L. (2016). "Changes in bacterial populations during bioremediation of soil contaminated with petroleum hydrocarbons. Water, Air and Soil Pollution, 91, 1-12.

Das, N.; Chandran, P. (2011). Microbial degradation of petroleum hydrocarbon Contaminants: An Overview. Biotechnology Research Internationa, 2011, 1-13.

Desai, H. (2015). "Isolation and Characterization Hydrocarbon Degrading Bacteria Isolated from Soil Contaminated with Engine Oil". Veer Narmad South Gujarat University, India

Gallego, J.L.R.; Loredo, J.; Llamas, J.F.; Vázquez, F.; Sánchez, J. (2001). Bioremediation of dieselcontaminated soils: evaluation of potential in situ techniques by study of bacterial degradation. Biodegradation. 12(5), 325-335.

Goodfello, M.; Williams, S. (1983). Ecology of actinomycetes. Ann. Re. Microbiol. 37, 189-216.

Graham, H.G.; Mcright, T.C.; Forfvich, E.D. (1962). Fertilizer material analysis, determine No. of calcium in phosphate material by titration with EDTA in the presence of calcein indicator. J. Agric. Food Che., 169, 447- 450.

Hamamura, M.; Ward, D.; Inskeep, W. (2013). Effects of petroleum mixture types on soil bacterial population dynamics associated with the biodegradation of hydrocarbons in soil environments, FEMS Microbiol Ecol.,85(1), 168-178.

Hussain, T.; Gondal, M.A. (2008). Monitoring and assessment of toxic metals in Gulf War oil spill contaminated soil using laser-induced breakdown spectroscopy. Environ. Monit. Assess. 136, 391-399.

Ijah, J.; Antai, S. (2003). The potential use of chicken-drop micro-organisms for oil spill remediation. Environmentalist. 23(1), 89-95.

Jackson, M.L. (1973). "Soil Chemical Analysis". Prentice Hall. New Delhi.

Jin, H.; Chen, L.; Wang, J.; Zhang, W. (2014). Engineering biofuel tolerance in non-native producing microorganisms. Biotechnol. Adv. 32(2), 541-548.

Kucharski, J.; Jastrzebska, E.; Wyszkowa, J. (2004). Effects of some oil products on the course of ammonification and nitrification. Acta. Agr. Silv. Ser. Agr., 42, 249-255.

Lawlor, K.; Sublette, K.; Duoncan, K.; Levetin, E.; Buck, P.; Wells, H. (1997). Long - term effects of crude oil contamination and bioremediation in a soil ecosystem. Bioremediation J.,1, 41-51.

Markowicz, A.; Plaza, G.; Piotrowska-Seget, Z. (2016). Activity and functional diversity of microbial community in long-term hydrocarbon and heavy metal contaminated soil. Archives of Environmental Protection, 42(4), 3-11. 
Megharaj, M.; Ramakrishnan, B.; Venkateswarlu, K.; Sethunathan, N.; Naidu, R. (2011). Bioremediation approaches for organic pollutants: A critical perspective. Environ. Int. 37(8), 1362-1375.

Mishra, S.; Jyot, J.; Kuhad, R.C.; Lal, B. (2001). In situ bioremediation potential of an oily sludgedegrading bacterial consor. Current Microbiol., 43, 328-335.

Olsen, S.R.; Cole, C.V.; Watanabe, F.S.; Dean, L.A. (1954). "Estimation of Available Phosphorus in Soil by Extraction with Sodium Bicarbonate". USDA Handbook.

Rahman, K.S.M.; Rahman, T.; Lakshmanaperumalsamy, P.; Banat, I. (2002a). Occurrence of crude oil degrading bacteria in gasoline and diesel station soils. J. Basic Microbiol. 42, 284-291.

Rahman, K.; Thahira-Rahman, J.; Lakshmanaperumalsamy, P.; Banat, I. (2002b). Towards efficient crude oil degradation by a mixed bacterial consortium. Bioresource Technol., 85, 257261.

Ron, E.Z.; Rosenberg, E. (2014). Enhanced bioremediation of oil spills in the sea. Curr. Opin. Biotechnol. 27, 191-194.

Sathishkumar, M.; Binupriya, A.R.; Baik, S.H.; Yun, S.E. (2008). Biodegradation of crude oil by individual bacterial strains and a mixed bacterial consortium isolated from hydrocarbon contaminated areas. Clean - Soil, Air, Water. 36(1), 92-96.

Schippers, A.; Schumann, P.; Sproer, C. (2005). Nocardioides oleiovorans sp. nov., a novel crudeoil- degrading bacterium. Int. J. Syst. Evol. Microbiol., 55, 1501- 1505.

Stanley, H.O.; Amakiri, M.A.; 1Okerentugba, P.O. (2015). Characterization of hydrocarbon utilizing bacteria in soil samples collected from variou sites in port harcourt (NigerDelta, Nigeria). G.J.B.B, 4(1), 6-11.

Varjani, S. (2017). Microbial degradation of petroleum hydrocarbons. Bioresour. Technol. 223, 277-286.

Varjani, S.; Upasani, V. (2013). Comparative studies on bacterial consortia for hydrocarbon degradation. Int. J. Innov. Res. Sci. Eng. Technol. 2(10), 5377-5383.

Viñas, M.; Sabaté, J.; Espuny, M.J.; Anna, M.; Vin, M. (2005). Bacterial community dynamics and polycyclic aromatic hydrocarbon degradation during bioremediation of heavily creosotecontaminated soil bacterial community dynamics and polycyclic aromatic hydrocarbon degradation during bioremediation of heavily creosote. Appl. Environ. Microbiol. 71, 7008-7018.

Wang, Z.; Fingas, M.; Blenkinsopp, S.; Sergy, G.; Landriault, M.; Sigouin, L. (1998). Comparison of oil composition changes due to biodegradation and physical weathering in different oils. J. Chromatogr. 809, 89-107.

Wyszkowska, J.; Kucharski, J. (2001). Role of Azotobacter sp. and adenine in yield formation of lettuce and bacteria abundance in soil. Scientific works of the Lithuanian Institute of Horticulare and Lithuanina. University of Agriculture, 3, 279-285

Xenia, M.E.; Refugio, R.V. (2016). Microorganisms metabolism during bioremediation of oil contaminated soils. J. Bioremed. Biodeg., 7(2), 2-6.

Zakaria, M.P. (2002). Distribution of polycyclic aromatic hydrocarbons (PAHs) in rivers and estuaries in Malaysia. A Widespread Input Petrogenic PAHs, Environ. Sci. Technol. 36(9), 1907-1918. 